\title{
FUNDAMENTAL MOVEMENT SKILLS: IDENTIFIKASI KETERAMPILAN GERAK DASAR OLAHRAGA PADA SISWA
}

\author{
Kusnandar ${ }^{1}$, Panuwun Joko Nurcahyo², Didk Rilastiyo Budi ${ }^{3}$ \\ 1,2,3 Jurusan Pendidkan Jasmani, Fakultas IImu-IImu Kesehatan Universitas Jenderal Soedirman \\ E-mail: kusnandar@unsoed.ac.id¹, panuwun.nurcahyo@unsoed.ac.id², \\ didik.rilastiyo.budi@unsoed.ac.id ${ }^{3}$ \\ DOI: https://doi.org/10.36526/kejaora.v6i2.1473
}

\begin{abstract}
ABSTRAK
Penelitian analisis keterampilan gerak olahraga berbasis Fundamental Movement Skills bertujuan untuk untuk mengukur dan mengetahui keterampilan gerak olahraga yang dimiliki oleh siswa SD dan SMP di Kecamatan Sumbang. Penelitian ini penting untuk dilakukan karena dengan diketahuinya tingkat keterampilan gerak olahraga pada siswa disetiap jenjang pendidikan maka akan membantu guru dan pelatih untuk membina anak dalam menggali potensi olahraga yang dimiliki sehingga dapat membantu anak untuk berkembang sesuai bakat dan dapat berprestasi tinggi di masa yang akan datang. Metode penelitian yang digunakan yaitu deskriptif kuantitatif, dengan pendekatan Survey. Instrumen yang digunakan dalam penelitian ini yaitu tes Fundamental Movement Skills untuk mengukur tingkat keterampilan gerak olahraga pada siswa. Sampel pada penelitian ini berjumlah 35 orang dengan rincian 25 siswa SD dan 15 siswa SMP. Hasil penelitian keterampilan gerak olahraga pada siswa SD menunjukan bahwa terdapat 12 anak yang berada pada kategori baik, 4 anak cukup dan 4 anak dalam kategori kurang. Sedangkan untuk siswa SMP menunjukan hasil 11 anak dengan kategori baik dan 4 anak cukup. Secara keseluruhan, siswa SD dan SMP di Desa Karanggintung, Sumbang memiliki rata-rata keterampilan gerak olahraga pada kategori baik. Hasil penelitian keterampilan gerak olahraga berbasis Fundamental Movement Skills akan memberikan dampak positif dalam menemukan dan menggali potensi keterampilan gerak pada siswa SD dan SMP di bidang olahraga.
\end{abstract}

Kata Kunci: Gerak Olahraga, Fundamental Movement Skill, Siswa SD dan SMP

\section{PENDAHULUAN}

Pertumbuhan dan perkembangan anak merupakan sesuatu yang kompleks. Artinya ada banyak faktor yang berpengaruh dan saling berhubungan dalam proses pertumbuhan dan perkembangan anak. Baik unsur-unsur bawaan maupun unsur-unsur pengalaman yang didapat dalam interaksi lingkungan. Yang keduanya (unsur bawaan dan lingkungan) memiliki pengaruh tertentu terhadap proses perkembangan anak tersebut. Salah satu faktor yang mempengaruhi perkembangan anak adalah proses pembelajaran penjas di sekolah (Budi, 2015; Tangahu, 2019; Nur et al., 2020). Sebab, proses tumbuh kembang anak akan mempengaruhi kehidupan mereka pada masa yang akan datang. Jika perkembangan anak tidak terpantau oleh guru terutama guru penjas dan orang tua (tanpa arahan dan pendampingan), maka anak akan tumbuh seadanya sesuai dengan yang pengalaman gerak yang mereka lakukan (Sayfei, et al., 2020; Kusnandar et al., 2021).

Perkembangan motorik anak merupakan salah satu aspek penting untuk kehidupannya selanjutnya. Prinsip perkembangan motorik adalah adanya suatu perubahan baik fisik maupun psikis sesuai dengan masa pertumbuhannya (Bakhtiar, 2015; Murti, 2018). Seiring dengan bertambahnya umur seorang anak maka akan banyak mendapatkan suatu hal yang berubah dalam tumbuh kembang hidupnya dengan kondisi lingkungan di sekitarnya. Hal lain yang berpengaruh terhadap perkembangan motorik anak adalah lingkungan tempat sekolah. Anak yang 
Jurnal Kejaora: Jurnal Kesehatan Jasmani dan Olah Raga

ISSN: 2541-5042 (Online)

ISSN: 2503-2976 (Print)

Volume 6 Nomor 2, Edisi November 2021

berada di lingkungan sekolah dengan sarana dan prasarana yang memadai akan berbeda dengan anak yang sekolah dengan keterbatasan sarana belajar.

Sehingga menarik ketika penelitian ini untuk melihat perkembangan gerak fundamental anak berupa kemampuan stability, locomotor, dan manipulasi anak berdasarkan pada tingkat SD dan SMP (initial, elementary, dan mature). Sarana bermain juga memfasilitasi pertumbuhan kognitif dan afektif pada anak-anak dan melalui media bermain, anak-anak prasekolah mengembangkan berbagai gerak fundamental anak diantaranya stabilitas, lokomotor dan kemampuan manipulatif (Gallahue and Donnelly, 2003; Macintyre, 2019).

Kabupaten Banyumas merupakan salah satu wilayah yang luas dan memiliki jumlah penduduk yang besar, akan tetapi sejauh ini belum pernah dilakukan penelitian mengenai identifikasi keterampilan gerak olahraga kepada anak-anak, sehingga dalam penentuan cabang olahraga terutama di Sekolah Dasar dan Sekolah Menengah Pertama, ditentukan berdasarkan minat siswa tanpa memperhatikan potensi dan bakat yang sesungguhnya dari siswa tersebut.

Aktivitas fisik dan olahraga menjadi bagian penting dalam perkembangan fisik dan motorik anak, terutama pada periode perkembangan usia sekolah, baik SD maupun SMP. Akan tetapi dalam perkembangan kemajuan zaman, keterampilan gerak olahraga sudah mulai ditinggalkan dan dianggap kurang penting oleh sebagian besar anak. Hasil penelitian menunjukan bahwa aktivitas fisik menurun dengan cepat selama masa kanak-kanak dan remaja (Burhaein, 2017). Penurunan tingkat keterlibatan fisik ini sangat tajam selama SMP (antara usia 13 dan 15) (Nader et al., 2008; Jaakkola and Washington, 2013).

Hasil penelitian lain menunjukan bahwa penilaian aktivitas fisik harus ditunjang dengan adanya Fundamental Movement Skills (FMS) sebagai faktor yang berpotensi signifikan dalam tingkat partisipasi aktivitas fisik remaja (Slade and Keating, 2007), selain itu penguasaan FMS juga akan

mempengaruhi terhadap keterampilan kecabangan olahraga (Barnett et al., 2016). Di dalam FMS terdiri dari tiga komponen utama yaitu: locomotor skills seperti: berlari, melompat, meluncur, dan memanjat (Budi et al., 2019). Balance skills seperti: menekuk, meregangkan, memutar, berbalik, mengguling, dan mendarat atau berhenti. Manipulative skills seperti: melempar, menangkap, memantulkan, menggulirkan bola, memvoli, dan mengayuh (Gallahue and Donnelly, 2003; Holfelder and Schott, 2014).

Penilaian pencapaian aktivitas fisik pasti akan ditunjang dengan FMS. FMS sudah tentu dimiliki oleh siswa dalam pembelajaran pendidikan jasmani baik siswa yang memiliki FMS tinggi maupun siswa yang memiliki FMS rendah sehingga dalam penelitian ini variabel FMS akan dijadikan sebagai variabel moderator dalam penentuan pencapaian aktivitas siswa dan kompetitif. Sedangkan untuk mengatasi masalah kurikulum yang lebih menekankan kepada keterampilan gerak siswa, kurang memberikan 50\% waktu belajar siswa terhadap aktivitas fisik, dan tidak memuat adanya kompetitif dalam pembelajaran diperlukan alat untuk menanggulangi masalah tersebut.

Penelitian ini mencoba mengisi gap penelitian yang telah ada dengan menggabungkan keterampilan gerak olahraga pada siswa SD dan SMP sehingga akan diketahui profil keterampilan gerak olahraga setiap siswa yang kemudian akan diberikan berbagai program pelatihan dan pembinaan keterampilan gerak di sekolah untuk mengembangkan potensi di bidang olahraga, terutama pada Sekolah Dasar dan Sekolah Menengah Pertama di Desa Karanggintung, Kecamatan Sumbang, Kabupaten Banyumas.

Penentuan siswa SD dan SMP di desa Karanggintung dilandasi data dilapangan karena Sebagian besar anak-anak terlibat aktif dalam berbagai latihan olahraga secara terprogram. Sehingga perlu diketahui kualitas gerak dasar olahraga yang dimiliki siswa, apakah sudah sesuai dengan tahap perkembangan atau belum.

Selain itu permasalahan yang terjadi yaitu belum pernah dilakukan tes identifikasi 
Jurnal Kejaora: Jurnal Kesehatan Jasmani dan Olah Raga

ISSN: 2541-5042 (Online)

ISSN: 2503-2976 (Print)

Volume 6 Nomor 2, Edisi November 2021

keterampilan gerak dasar olahraga pada siswa SD maupun SMP di daerah tersebut. Sehingga belum teridentifikasi secara pasti apakah kualitas gerak siswa SD maupun SMP memiliki kualitas yang sama atau berbeda.

Atas dasar keterangan dan berbagai hasil penelitian tersebut, maka penting untuk meneliti mengenai Identifikasi Keterampilan Gerak Olahraga Berbasis Fundamental Movement Skills Pada Siswa SD dan SMP di Kecamatan Sumbang. Melalui sasaran dekat dalam penelitian ini akan dapat tingkat keterampilan gerak olahraga pada siswa SD dan SMP di Desa Karanggintung Kecamatan Sumbang, Kabupaten Banyumas, sehingga akan dapat memprediksi apakah keterampilan gerak anak dalam kondisi sesuai dengan perkembangan usia atau berada pada tingkat perkembangan gerak yang tidak sesuai perkembangan umur. Dengan diketahuinya keterampilan gerak olahraga maka akan dapat diberikan program latihan dan pembinaan yang tepat di sekolah untuk membantu siswa memiliki keterampilan gerak olahraga yang baik.

\section{METODE}

Penelitian yang akan penulis lakukan ini menggunakan metode deskriptif kuantitaif dengan tengan pendekatan survey. Hal ini dikarenakan peneliti tidak melakukan intervensi terhadap sampel penelitian dalam mengidentifikasi keterampilan gerak dasar olahraga pada sampel.

Populasi penelitian ini adalah siswa Sekolah Dasar dan Siswa Sekolah Menengah Pertama di Kecamatan Sumbang, sedangkan Populasi terjangkau dari penelitian ini adalah siswa Sekolah Dasar dan Siswa Sekolah Menengah Pertama di Kecamatan Sumbang. Sampel penelitian adalah sebagian siswa Sekolah Dasar Kelas IV-V dan Siswa Sekolah Menengah Pertama Kelas VII-VIII di Kecamatan Sumbang. Dengan menggunakan Teknik Purposive Sampling dengan kriteria sebagai berikut: a) anak bersedia menjadi sampel penelitian; b) anak dalam kondisi sehat dan tidak cedera; c) mengikuti program ektrakurikuler di sekolah; dan d) bertempat tinggal di Desa Karanggintung Kecamatan Sumbang.

Berdasrkan kriteria tersebut maka diperoleh sampel sebanyak 20 orang siswa SD dan 15 orang siswa SMP dengan jumlah sampel sebanyak 35 orang.

Instrumen untuk mengukur keterampilan gerak dasar olahraga dilakukan dengan melakukan tes Fundamental Movement Skills yang penulis adopsi dari Gallahue, (2003) yang memaparkan mengenai 24 tugas fisik yang harus dilakukan dengan validitas dan reliabilitas tes 0.76 (Gallahue and Donnelly, 2003; Apriani, Suntoda and Budiman, 2018; Eddy et al., 2020).

Untuk menjaga data penelitian bersifat objektif maka pada proses penilaian keterampilan gerak Fundamental Movement Skills yang dilakukan oleh siswa, dilakukan dengan melibatkan 3 orang penilai yang terdiri dari tim peneliti dan dosen bidang olahraga yang sudah berkompeten.

Fundamental Movement Skills yang dijelaskan oleh Gallahue terdapat tiga jenis kemampuan gerak dasar, yaitu Stability Skill, Locomotor Skills dan Manipulative Skills. Dari masing-masing gerakan terdapat sub gerakan yang termasuk ke dalam masingmasing kategori. Kemudian setiap gerak memiliki tingkatan dan kompleksitas gerakan yang berbeda, yang dibagi menjadi tiga tahap, yaitu Initial Stage, Elementary Stage dan Mature Stage. Dengan ketentuan penilaian tertera pada tabel 1 . sebagai berikut.

Tabel 1. Kriteria Fundamental Movement SKills

\begin{tabular}{lc}
\hline Kriteria gerakan & Poin \\
\hline $\begin{array}{l}\text { Gerakan sesuai dengan tahap } \\
\text { perkembangan (Baik) }\end{array}$ & 3 \\
$\begin{array}{l}\text { Gerakan cukup sesuai dengan tahap } \\
\text { perkembangan (Cukup) }\end{array}$ & 2 \\
$\begin{array}{l}\text { Kriteria gerakan tidak sesuai dengan } \\
\text { tahap perkembangan (Kurang) }\end{array}$ & 1 \\
\hline
\end{tabular}

Prosedur pengambilan data dilakukan dengan cara melakukan tes keterampilan gerak dasar pada siswa SD dan SMP, kemudian setelah data hasil tes keterampilan gerak dasar olahraga dianalisis secara deskriptif berdasarkan kriteria keterampilan gerak yang dimiliki oleh siswa. 
Jurnal Kejaora: Jurnal Kesehatan Jasmani dan Olah Raga

ISSN: 2541-5042 (Online)

ISSN: 2503-2976 (Print)

Volume 6 Nomor 2, Edisi November 2021

\section{HASIL DAN PEMBAHASAN}

Berdasarkan data Fundamental Movement Skills (FMS) diperoleh hasil klasifikasi keterampilan gerak dasar olahraga pada siswa SD dan SMP dapat dilihat pada tabel 2. dibawah ini.

Tabel 2. Data Keterampilan Gerak Dasar Olahraga Fundamental Movement Skills Siswa SD

\begin{tabular}{lllll}
\hline \multirow{2}{*}{ No } & \multirow{2}{*}{ L/P } & FMS & & \\
& & Baik & Cukup & Kurang \\
\hline 1 & Laki-laki & 3 & 2 & 3 \\
2 & Perempuan & 9 & 2 & 1 \\
& Jumlah & $\mathbf{1 2}$ & 4 & 4 \\
\hline
\end{tabular}

Berdasarkan tabel diatas terlihat bahwa dari 20 sampel menunjukan bahwa keterampilan gerak dasar olahraga yang dimiliki oleh siswa SD menunjukan bahwa 12 orang dalam kategori baik, 4 orang kategori cukup dan 4 orang berada pada kategori kurang. Selanjutnya yaitu data hasil keterampilan gerak dasar olahraga pada siswa SMP terlihat pada tabel 3 dibawah ini.

Tabel 3. Data Keterampilan Gerak Dasar Olahraga Fundamental Movement Skills Siswa SMP

\begin{tabular}{lllll}
\hline \multirow{2}{*}{ No } & \multirow{2}{*}{ L/P } & FMS & & \\
& & Baik & Cukup & Kurang \\
\hline 1 & Laki-laki & 8 & 2 & \\
2 & Perempuan & 3 & 2 & \\
& Jumlah & 11 & 4 & 0 \\
\hline
\end{tabular}

Berdasarkan tabel diatas terlihat bahwa dari 15 sampel menunjukan bahwa keterampilan gerak dasar olahraga yang dimiliki oleh siswa SMP menunjukan bahwa 11 orang dalam kategori baik, 4 orang kategori cukup dan tidak ada siswa yang berada pada kategori kurang. Selanjutnya yaitu data perbandingan keterampilan gerak dasar olahraga pada siswa SD dan SMP terlihat pada tabel 4 dibawah ini.
Tabel 4. Data Perbandingan Keterampilan Gerak Dasar Olahraga Fundamental Movement Skills Siswa SD dan SMP

\begin{tabular}{lllll}
\hline \multirow{2}{*}{ No } & \multirow{2}{*}{ Sampel } & FMS & & \\
& & Baik & Cukup & Kurang \\
\hline 1 & SD Putra & 3 & 2 & 3 \\
2 & SMP Putra & 8 & 2 & \\
3 & SD Putri & 9 & 2 & 1 \\
4 & SMP Putri & 3 & 2 & \\
& Jumlah & $\mathbf{2 3}$ & $\mathbf{8}$ & 4 \\
\hline
\end{tabular}

Berdasarkan tabel diatas terlihat bahwa dari 35 sampel menunjukan bahwa keterampilan gerak dasar olahraga yang dimiliki oleh siswa SD dan SMP menunjukan bahwa 23 orang dalam kategori baik, 8 orang kategori cukup dan 4 orang berada pada kategori kurang.

Berdasarkan hasil penelitian menunjukan bahwa siswa SD dan SMP memiliki keterampilan gerak dasar olahraga dengan kategori baik, berdasarkan hasil tes Fundamental Movement Skills (FMS). Keterampilan gerak yang baik pada dasarnya dikarenakan anak telah terbiasa melakukan berbagai keterampilan gerak olahraga dalam bentuk permainan.

Hasil penelitian terdahulu menunjukan bahwa keterampilan motorik dapat ditingkatkan dengan berbagai bentuk permainan (Holfelder and Schott, 2014; Barnett et al., 2016; Setiawan et al., 2020). Sehingga penting bagi usia anak SD dan SMP melakukan berbagai keterampilan gerak untuk memperkaya keterampilan motorik yang dimiliki.

Gerakan multilateral penting diberikan kepada anak karena merupakan dasar dari gerakan olahraga di masa yang akan datang (Darmawan and Maulana, 2019; Ristanti et al., 2019; Kusuma et al., 2019). Pentingnya keterampilan gerak dasar olahraga harus menjadi perhatian khusus bagi guru dan pelatih yang membina anak usia sekolah. Sehingga tidak menghambat proses pertumbuhan dan perkembangan motorik anak.

Program keterampilan gerak dasar olahraga dalam bentuk permainan yang bersifat multilateral perlu diberikan kepada 
Jurnal Kejaora: Jurnal Kesehatan Jasmani dan Olah Raga

ISSN: 2541-5042 (Online)

ISSN: 2503-2976 (Print)

Volume 6 Nomor 2, Edisi November 2021

anak sebelum anak melakukan Gerakan olahraga kecabangan yang spesifik.

\section{KESIMPULAN}

Berdasarkan hasil dan pembahasan menunjukan bahwa keterampilan gerak dasar olahraga yang dimiliki oleh siswa SD di desa Karanggintung, kecamatan Sumbang berada pada kategori baik. Keterampilan gerak dasar olahraga pada siswa SMP menunjukan bahwa rata-rata siswa memiliki keterampilan gerak yang baik. berdasarkan hal tersebut maka dapat disimpulkan bahwa siswa SD dan SMP di desa Karanggintung Kecamatan Sumbang memiliki keterampilan gerak olahraga yang baik.

Rekomendasi untuk penelitian selanjutnya berdasarkan hasil penelitian yaitu perlu diberikan tes selain Fundamental Movement Skills (FMS) untuk memastikan keterampilan gerak yang dimiliki anak benarbenar dalam kategori baik. jenis tes yang dapat diterapkan yaitu Gross Motor Skills, Motor Educability Tes dan jenis tes lain yang disesuaikan dengan tahapan pertumbuhan dan perkembangan anak.

\section{UCAPAN TERIMA KASIH}

Terima kasih kami sampaikan kepada kepada Universitas Jenderal Soedirman yang telah memberikan dana hibah penelitian kepada peneliti melalui Skim Riset Peningkatan Kompetensi. Terima kasih kami sampaikan juga kepada seluruh sampel penelitian yang telah bekerjasama dalam proses penelitian, sehingga dapat berjalan dengan baik.

\section{DAFTAR PUSTAKA}

Apriani, I., Suntoda, A. and Budiman, D. (2018) 'Uji Validitas Dan Reliabilitas Test Of Gross Motor Development-2 (TGMD-2) Dale A. Ulrich Pada Anak 9 Tahun', TEGAR: Journal of Teaching Physical Education in Elementary School, 2(1). doi: 10.17509/tegar.v2i1.13780.

Arief Darmawan and Amir Maulana (2019) 'Pengembangan Model Pembelajaran Permainan Motorik Halus Untuk Anak Usia Dini', Jurnal Kejaora (Kesehatan Jasmani dan Olahraga), 4(2), pp. 23-

27. doi: 10.36526/kejaora.v4i2.721.

Bakhtiar, S. (2015) Merancang Pembelajaran Gerak Dasar Anak, Merancang Pembelajaran Gerak Dasar Anak.

Barnett, L. M. et al. (2016) 'Fundamental movement skills: An important focus', Journal of Teaching in Physical Education. doi: 10.1123/jtpe.20140209.

Budi, D. R. (2015) 'Pengaruh Modifikasi Permainan Vobas dan Kebugaran Jasmani terhadap Peningkatan Kerjasama Siswa dalam Pembelajaran Penjas di SMP', Thesis.

Budi, D. R. et al. (2019) 'The Analysis of Fundamental Movement Skill in Primary School Student in Mountain Range', 11(Icsshpe 2018), pp. 195198. doi: 10.2991/icsshpe18.2019.56.

Burhaein, E. (2017) 'Aktivitas Fisik Olahraga untuk Pertumbuhan dan Perkembangan Siswa SD', Indonesian Journal of Primary Education. doi: 10.17509/ijpe.v1i1.7497.

Denis Febryanto Tangahu (2019) 'Pengaruh Model Pembelajaran Tgfu Dan Tgt Terhadap Academic Learning Time', Jurnal Kejaora (Kesehatan Jasmani dan Olahraga), 4(2), pp. 28-35. doi: 10.36526/kejaora.v4i2.745.

Dewi Irma Ristanti, Wawan Setiawan and Donny Setiawan (2019) 'Pengaruh Pembelajaran Menggunakan Media Hullahop Terhadap Peningkatan Hasil Belajar Senam Lantai Pada Siswa Kelas VIII Di SMP Negeri 1 Pakusari', Jurnal Kejaora (Kesehatan Jasmani dan Olahraga). doi: 10.36526/kejaora.v4i1.617.

Eddy, L. H. et al. (2020) 'The validity and reliability of observational assessment tools available to measure fundamental movement skills in school-age children: A systematic review', PLOS ONE, 15(8 August 2020), pp. 1-29. doi: 10.1371/journal.pone.0237919.

Gallahue, D. L. and Donnelly, F. C. (2003) 'Developmental physical education for all children', Revista de investigación 
Jurnal Kejaora: Jurnal Kesehatan Jasmani dan Olah Raga

ISSN: 2541-5042 (Online)

ISSN: 2503-2976 (Print)

Volume 6 Nomor 2, Edisi November 2021

clínica; organo del Hospital de Enfermedades de la Nutrición.

Holfelder, B. and Schott, N. (2014) 'Relationship of fundamental movement skills and physical activity in children and adolescents: A systematic review', Psychology of Sport and Exercise. doi: 10.1016/j.psychsport.2014.03.005.

Jaakkola, T. and Washington, T. (2013) 'The relationship between fundamental movement skills and self-reported physical activity during Finnish junior high school', Physical Education and Sport Pedagogy. doi: 10.1080/17408989.2012.690386.

Kusnandar et al. (2021) 'Elementary Student's Physical Activity during Pandemic Covid 19', Annals of Tropical Medicine \& Public Health, 24(03), pp. 10-16. doi: 10.36295/asro.2021.24329.

Kusuma, M. N. H., Syafei, M. and Budi, D. R. (2019) Biomekanika Olahraga. Purwokerto: Unsoed Press.

Macintyre, C. (2019) 'Understanding motor development', in Understanding Children's Development in the Early Years. doi: 10.4324/97813157763475.

Murti, T. (2018) 'Perkembangan Fisik Motorik dan Perseptual Serta Implikasinya pada Pembelajaran di Sekolah Dasar', Wahana Sekolah Dasar. doi: 10.17977/um035v26i12018p021.

Nader, P. R. et al. (2008) 'Moderate-tovigorous physical activity from ages 9 to 15 years', JAMA - Journal of the American Medical Association. doi: 10.1001/jama.300.3.295.

Nur, L. et al. (2020) 'Comparison of two types of instruction in physical education', International Journal of Psychosocial Rehabilitation, 24(10), pp. 1785-1793. doi: 10.37200/IJPR/V24I10/PR300205.

Sayfei, M. et al. (2020) 'Identifikasi Keberbakatan Menggunakan Metode Australian Sport Search Terhadap Kesesuaian Cabang Olahraga Pada Anak Sekolah Dasar', Physical Activity Journal.

doi: 